\title{
Effects of lignohumate and biochar on plant responses in humus-poor and humus-rich soils polluted with metals
}

\author{
Kiryushina A.P. ${ }^{1}$, Paramonova A.I. ${ }^{1,2}$, Korolev P.A. ${ }^{1,2}$, Uchanov P.V. ${ }^{1}$, Terekhova V.A. ${ }^{2}$ \\ ${ }^{1}$ Institute of Ecology and Evolution, Russian Academy of Sciences, Moscow, Russia \\ 2Lomonosov Moscow State University, Moscow, Russia, vterekhova@gmail.com \\ doi: 10.36291/HIT.2019.kiryushina.063
}

Various organic materials are widely used in agriculture with the aim of improving soil quality, plant nutrients regime, and plant production. Both lignohumate and biochar, coproducts of thermochemical conversion of lignocellulosic materials, are marketed as universal soil improvers [1,2]. Their sorption properties are especially relevant in case of polymetallic soil contamination, since these substances have a sufficiently high exchange capacity with respect to metals. However, rather conflicting data on the effectiveness of these products as well as ambiguous effects of their combined and separate applications are published.

We investigated the impact of biochar (70-80\% pure carbon, Company "Metakom", Russia) and lignohumate (C total $36 \%$, Company "RET", Russia) on plant responses in two typical agricultural topsoils $(0-20 \mathrm{~cm})$ : Chernozem (Voronezh region, organic carbon $5.4 \%$ ) and Agrozem (rice fields of Kalmykia, organic carbon 1.5\%). Natural and metalspiked $(650 \mathrm{mg} / \mathrm{kg} \mathrm{Pb}+1100 \mathrm{mg} / \mathrm{kg} \mathrm{Zn}+660 \mathrm{mg} / \mathrm{kg} \mathrm{Cu})$ soil samples were analyzed. One week after metal spiking, biochar $(5 \%)$ and lignohumate $(0.25 \%)$ were added. The pots with soil samples were incubated for 120 days at $22-24^{\circ} \mathrm{C}$ and $60 \%$ relative humidity. We analysed growth parameters (seeds germination, roots and sprouts length) of seedlings of three species: Sinapis alba (mustard), Raphanus sativus (radish), Avena sativa (oat). Each experimental had 3 replicates.

The results indicate that: 1 ) effects of exogenous organic matter application on plant responses varied greatly between humus-poor and humus-rich soils; biochar and lignohumate amendments significantly increased plant root and spout length in chernozem, whereas their effect was slight in the humus-poor soil; 2) effect of lignohumate and biochar mixture was significantly higher than that of lignohumate amendments (radish and oat - roots length more for $39-36 \%$ and roots length - 25-28\%); 3 ) biochar added to humus-poor soil caused a strong inhibitory effect on seed germination of all plant species, sprout length by $35 \%$, and root length by $15 \%$; the combined introduction of lignohumate and biochar had a small positive effect only on oats. Interestingly, on unpolluted samples test parameters of $A$. sativa were more informative, while in the presence of heavy metals in the samples, plant reactions to biochar and lignohumate were better seen on mustard S. alba which is used as green fertilizer ("green manure crops") or "siderites".

Thus, the results indicate that effectiveness of biochar and lignohumate amendments (both alone and in mixtures) have the potential to substantially improve the quality and fertility status of a certain type of agricultural soils polluted with high concentrations $\mathrm{Cu}, \mathrm{Pb}$ and $\mathrm{Zn}$. No significant plant-stimulating effects were detected in humus-poor soil neither in polluted any un-polluted samples.

Acknowledgements. The work is supported by the RFBR (project 18-04-01218-a).

\section{References}

1. Perminova I.V. et al. // In: Viable Methods of Soil and Water Pollution Monitoring, Protection and Remediation, Springer Netherlands, 69:249-274.

2. Pospíšlová L'. et al. // J. Life Sciences. 2016. 10:153-160. 